\title{
ПРАВОВІ ПІДТАВИ ДІЯЛЬНОСТІ ПОЛІЦЕЙСЬКИХ ПАТРУЛЬНОї ПОЛІЦІї НПУ
}

\author{
ОСТАПОВИЧ Володимир Петрович - кандидат юридичних наук, завідувач \\ лабораторії психологічного забезпечення Державного науково-дослідного \\ інституту Міністерства внутрішніх справ України, м. Київ (Україна) \\ DOI:10.32782/EP.2020.1.17
}

\begin{abstract}
Стаття присвячена дослідженню правових підстав діяльності поліцейсъких патрульної полічї Національної поліцї Украӥни. У ній розглянуто нормативне визначення професій поліщейсъкого патрульної полічій НПу; проаналізовані завдання, обов'язки, відповідальність та права патрульних; визначені основні приниипи, якими має керуватися патрульний у своїй професійній діяльності; встановлені вимоги, яким має відповідати кандидат для роботи полічейсъким патрульної поліщї; виявлені найбільш типові помилки, що можуть мати місце в діяльності патрульного та їх можливі наслідки.

Ключові слова: Начіональна полічія України, патрульна поліція, правові підстави професійної діяльності
\end{abstract}

\section{Вступ}

Національна поліція України перебуває на шляху подальшого вдосконалення діяльності та реформування. Закон України «Про Національну поліцію» [1] спрямовує діяльність нового правоохоронного органу на неухильне дотримання законності та прав людини, демілітаризацію, взаємодію 3 населенням, відкритість і профілактичний підхід, збільшення управлінської гнучкості, ініціативності персоналу й керівників, поліпшення системи професійного навчання.

Важливі завдання стоять сьогодні перед сучасною патрульною поліцією Національної поліції України. Насамперед, це забезпечення публічного порядку та безпеки, охорони прав і свобод людини, а також інтересів суспільства і держави; запобігання, виявлення та припинення кримінальних та адміністративних правопорушень; забезпечення безпеки дорожнього руху, організація контролю за додержанням законів, інших нормативних актів 3 питань безпеки дорожнього руху, надання послуг 3 допомоги особам, які з особистих, економічних, соціальних причин або внаслідок надзвичайних ситуацій потребують такої допомоги. Від підрозділів патрульної поліції очікується суттєве покращання й підвищення ефективності діяльності, яке грунтується на доборі персоналу з високим рівнем професійної придатності до виконання обов’язків, подальшому підвищенні професійної підготовленості поліцейських, досягнення більш вагомих результатів у справі боротьби зі злочинністю і захисті конституційних прав і свобод громадян.

Важливою складовою якісного кадрового забезпечення підрозділів патрульної поліції Національної поліції України кваліфікованим персоналом є добір на основі об'єктивного оцінювання наявності необхідних компетенцій - правових знань, а також багатьох спеціальних умінь. Тому особливої актуальності набуває сьогодні вивчення правових підстав діяльності поліцейського патрульної поліції Національної поліції України. Правова підготовка та правова обізнаність поліцейських патрульної поліції є важливим завданням і необхідною передумовою вирішення проблем, 
пов'язаних з ефективним виконанням своїх професійних обов'язків, підвищення їх кваліфікації, підготовки та перепідготовки, раціоналізацією режимів і умов праці, зниженням травматизму і професійних захворювань.

Метою дослідження правових підстав діяльності поліцейського патрульної поліції 6 вивчення особливостей професії 3 розкриттям змісту трудової діяльності, а також визначення правових вимог, які пред'являються до працівників, сукупності професійно важливих якостей, необхідних для оволодіння професією, створення на їх грунті еталонної моделі професіонала-поліцейського.

Основні завдання наукової роботи:

1. 3'ясувати нормативне визначення професії поліцейського патрульної поліції у Національному класифікаторі України «Класифікатор професій».

2. Надати загальну правову характеристику професійної діяльності поліцейського патрульної поліції: основні завдання, обов'язки, відповідальність та права.

3. Визначити основні принципи, якими має керуватися працівники патрульної поліції у своїй професійній діяльності.

4. Встановити, яким вимогам має відповідати кандидат для роботи патрульним поліцейським.

5. Виявити найбільш типові помилки, що можуть мати місце в діяльності поліцейських патрульної поліції, та їх можливі наслідки.

\section{Виклад основного матеріалу}

За Національним класифікатором України «Класифікатор професій» ДК 003:2010 [2] посада поліцейського патрульної поліції віднесена до розділу 3 «Фахівці», код підкласу - 3451, назва класифікаційного угрупування - «Інспектори правоохоронних органів та фахівці із дізнання», код КП (згідно з покажчиком професійних назв робіт за кодами професій) - 3451, професійна назва роботи - «Інспектор (органи внутрішніх справ)».

у Національному класифікаторі ДК 003:2010 професія поліцейського патрульної поліції нормативно не визначена, а перебуває в межах узагальненої назви професійної роботи - «нспектори правоохоронних органів та фахівці із дізнання».

Відповідно до законодавства та інших нормативно-правових актів $[1 ; 3 ; 4 ; 5 ; 6]$ поліцейський патрульної поліції у процесі службової діяльності виконує наступні завдання:

- патрулювання території обслуговування з метою забезпечення публічної безпеки і порядку, контролю за дотриманням правил дорожнього руху, забезпечення його безпеки та за правомірністю експлуатації транспортних засобів на вулично-дорожній мережі;

- первинне реагування на повідомлення про правопорушення, а також самостійне виявлення правопорушень під час патрулювання та в інших випадках, передбачених законодавством;

- надання невідкладної допомоги, зокрема домедичної допомоги особам, які постраждали внаслідок правопорушень, нещасних випадків, а також особам, які опинилися в безпорадному стані або стані, небезпечному для їхнього життя чи здоров'я;

- вжиття заходів для визначення осіб, які не здатні через стан здоров'я, вік або інші обставини повідомити інформацію про себе;

- припинення виявлених кримінальних та адміністративних правопорушень, застосовуючи для цього передбачені законодавством повноваження;

- розгляд справ про адміністративні правопорушення, застосовує заходи адміністративного впливу до правопорушників, у випадках та в спосіб, які передбачені законодавством;

- затримання осіб на підставах i у порядку, передбачених законодавством, а також доставляє затриманих осіб, підозрюваних у вчиненні кримінального правопорушення, та осіб, які вчинили адміністративне правопорушення (у визначених законодавством випадках) до підрозділів Національної поліції України та/або до суду; 


\section{Кримінальне право, кримінальний процес та криміналістика}

- охорону місця події з метою забезпечення подальшого розслідування, а також вживає заходів щодо охорони та збереження місця події в первинному, незміненому стані до прибуття уповноважених осіб, зокрема слідчих оперативних груп [6].

у сфері забезпечення безпеки дорожнього руху патрульний поліцейський під час несення служби здійснює також:

- організацію безпечного та безперешкодного дорожнього руху;

- контроль за дотриманням учасниками дорожнього руху правил, норм і стандартів, діючих у сфері безпеки дорожнього pyxy;

- з'ясування обставини, що призвели до дорожньо-транспортної пригоди;

- регулювання дорожнього руху, забезпечення організації руху транспортних засобів і пішоходів у місцях проведення аварійно-рятувальних робіт, масових заходів та під час виникнення заторів;

- спільно 3 іншими підрозділами Національної поліції України розшук транспортних засобів, водії яких зникли з місця скоєння ДТП, та транспортних засобів, які викрадені або якими незаконно заволоділи в межах території обслуговування під час введення відповідного оперативного плану;

- надання практичної допомоги учасникам дорожнього руху;

- заходи із забезпечення провадження у справах про адміністративні правопорушення, у тому числі тимчасове затримання транспортних засобів і доставка на спеціальні майданчики чи стоянки;

- профілактику, попередження та припинення злочинів і адміністративних правопорушень у сфері дорожнього руху [6].

У сфері забезпечення публічної безпеки і порядку патрульний поліцейський під час несення служби здійснює також:

- забезпечення публічної безпеки і порядку під час проведення масових заходів;

- спілкування і співпрацю із суспільством, реалізовуючи підхід «поліція та гро- мада», а також постійно співпрацює 3 населенням та громадськими організаціями 3 метою підвищення рівня публічної безпеки і порядку, запобігання вчиненню правопорушень та встановлення довірливих відносин між поліцією та населенням;

- застосування службового коня відповідними підрозділами при здійсненні патрулювання, при переслідуванні та затриманні особи, яка підозрюеться у вчиненні кримінального правопорушення;

- у випадках та в межах, передбачених законодавством України, виконує інші функції, спрямовані на реалізацію своїх завдань

- співпрацю 3 іншими підрозділами Національної поліції України;

- інші функції, передбачені законодавством [6].

Під час виконання службових обов’язків поліцейський патрульної поліції зобов'язаний:

- неухильно дотримуватися положень Конституції України, законів України та інших нормативно-правових актів, що регламентують діяльність патрульної поліції, а також Присяги поліцейського;

- контролювати безперебійність радіозв’язку, Інтернет зв'язку, а в разі відсутності такого зв'язку, негайно вживати всіх можливих заходів щодо інформування про це чергової служби та командира роти або заступника командира роти;

- дотримуватись встановленого однострою поліцейського патрульної поліції;

- постійно утримувати у належному стані спеціальні засоби захисту, елементи екіпірування, транспортні засоби та їх обладнання, технічні засоби та технічні прилади, які використовуються для фіксації правопорушень, засоби зв'язку, медичне устаткування для надання першої медичної допомоги;

- знати оперативну обстановку, що доводиться на інструктажах, насамперед стан аварійності та злочинності; 
- поважати i дотримуватись прав та свобод людини і громадянина, обмежувати їх лише в спосіб та у випадках, що встановлені законом;

- під час спілкування 3 громадянами дотримуватися правил поведінки та професійної етики;

- звертаючись до особи або у разі звернення особи до поліцейського, поліцейський зобов' язаний назвати своє прізвище, посаду, спеціальне звання та пред'явити на iii вимогу службове посвідчення, надавши можливість ознайомитися 3 викладеною в ньому інформацією, не випускаючи його 3 рук;

- не розголошувати інформацію 3 обмеженим доступом, яка стала йому відома у зв'язку з виконанням службових обов'язків;

- професійно виконувати свої службові обов'язки і накази керівництва, постійно і наполегливо самовдосконалюватись, підвищувати рівень довіри суспільства до поліції;

- у разі отримання інформації про можливе вчинення корупційного чи дисциплінарного правопорушення негайно інформувати безпосереднього керівника та (або) служби моніторингу патрульної поліції, і вжити заходів щодо його запобігання та припинення;

- під час керування патрульним автомобілем бути прикладом для інших учасників дорожнього руху в частині дотримання ПДР;

- виконувати інші обов'язки поліцейського відповідно до законодавства, нормативно-правових актів Міністерства внутрішніх справ України та організаційнорозпорядчих документів Національної поліції України [6].

Поліцейський патрульної поліції має право:

- вимагати від будь-якої особи дотримання публічного порядку та безпеки, прав і свобод людини, а також інтересів суспільства і держави; вимагати припинення правопорушень;
- використовувати технічні прилади і технічні засоби, що мають функції фото- і кінозйомки, відеозапису, засобів фото- і кінозйомки, відеозапису для виявлення і фіксації правопорушень, зокрема нагрудні відеокамери (відеореєстратори);

- вимагати від особи пред'явлення документів, що посвідчують іï особу, та (або) документів, що підтверджують відповідне право особи у випадках, передбачених законодавством;

- здійснювати в установленому законодавством порядку поверхневу перевірку та огляд осіб, речей або транспортних засобів;

- проникати до житла чи іншого володіння осіб у випадках, передбачених законодавством;

- вимагати від особи (осіб) залишити визначене місце на певний строк;

- тимчасово обмежити або заборонити доступ особам до визначеної території або об'єктів, якщо це необхідно для забезпечення публічного порядку та громадської безпеки, охорони життя і здоров'я людей, охорони місця події, проведення слідчих дій;

- затримувати особу на підставах i y порядку, передбачених законом, а також здійснювати ії доставляння до підрозділів Національної поліції України;

- перевіряти дотримання обмежень, установлених законом стосовно осіб, які перебувають під адміністративним наглядом та інших категорій осіб;

- здійснювати поліцейське піклування в порядку, передбаченому

- застосовувати заходи фізичного впливу, спеціальні засоби та вогнепальну зброю у випадках і в порядку, передбачених законодавством;

- зупиняти транспортні засоби, у випадках передбачених законодавством;

- затримувати та організовувати доставляння транспортних засобів для тимчасового зберігання на спеціальних майданчиках і стоянках; 


\section{Кримінальне право, кримінальний процес та криміналістика}

- обмежувати або забороняти у визначених законом випадках рух і перебування транспортних засобів і громадян на окремих ділянках вулиць і автомобільних доріг;

- при здійсненні патрулювання на транспортному засобі використовувати спеціальні світлові та звукові сигнальні пристрої, а також, у випадках службової необхідності, відступати від правил дорожнього pyxy;

- використовувати інші повноваження, визначені законодавством України [6].

Поліцейський патрульної поліції провадить свою діяльність на принципах верховенства права, дотримання прав і свобод людини, законності, відкритості та прозорості, політичної нейтральності, взаємодії 3 населенням на засадах партнерства.

Поліцейський патрульної поліції керуються в роботі: Конституцією України [7], Законами України «Про Національну поліцію» [1], «Про Дисциплінарний статут Національної поліції України» [8], «Про запобігання корупції» [9], «Про захист персональних даних» [10], «Про доступ до публічної інформації» [11], «Про звернення громадян» [12], «Про дорожній рух» [13], Кодексом України про адміністративні правопорушення [14], Кримінальним кодексом України [15], Кримінально процесуальним кодексом України [16], Постановою КМУ «Правилами дорожнього руху» [17], Положенням про Департамент патрульної поліції [18], нормативно-правовими актами, що регламентують діяльність Департаменту, іншими актами законодавства України, нормативно-правовими актами Міністерства внутрішніх справ України та Національної поліції України.

Критеріями оцінки ефективності діяльності поліцейського патрульної поліції $\epsilon$ стан - злочинності, публічної безпеки і порядку, безпеки дорожнього руху та зокрема особистий внесок поліцейського у попередження і розкриття злочинів та правопорушень, своєчасний та якісний розгляд звернень громадян, особисте дотримання дисципліни і законності.

Професійні функції поліцейського патрульної поліції характеризуються різнобічністю. Особливість діяльності поліцейського патрульної поліції полягає у тісному і постійному контакті з населенням. Рівень відповідальності службової діяльності поліцейського патрульної поліції - дуже високий, що пов'язано із частим прийняттям рішень одноосібно та різноплановістю службової діяльності.

Узагальнення змісту професійної діяльності поліцейських патрульної поліції дозволяє визначити основні її характеристики, які вирізняють ії серед інших видів професійної діяльності. До них належать:

- широкий спектр завдань професійної діяльності (здійснює реалізацію завдань 3 питань забезпечення публічного порядку, громадської безпеки і безпеки дорожнього руху та запобігання правопорушенням);

- часта зміна об'єктів професійної діяльності (необхідність оперативного реагування на професійні ситуації, що можуть виникати одночасно);

- одноосібність у прийнятті рішень і висока відповідальність за них;

- владні повноваження;

- висока інтенсивність професійних взаємодій;

- постійні просторові переміщення в межах визначеної ділянки місцевості;

- виконання інших повноважень, передбачених нормативно-правовими актами МВС [19].

Виконання поліцейським патрульної поліції службових обов'язків потребує від нього правових знань, а також багатьох спеціальних умінь.

Поліцейський патрульної поліції повинен знати:

- Конституцію України; акти законодавства, що стосуються діяльності Національної поліції України; укази Президента України, постанови Верховної Ради України, постанови та розпорядження Кабінету 
Міністрів України, розпорядчі документи МBC України, інші нормативно-правові акти, інструктивні та методичні документи, що регулюють діяльність патрульної поліції та зокрема з питань забезпечення безпеки дорожнього руху, а також взаємодію 3 органами державної влади та органами місцевого самоврядування; відомчі та міжнародні нормативні документи, що регулюють питання дотримання поліцейськими прав людини; організаційну структуру та особливості діяльності підрозділів Національної поліції України;

- місце і завдання Національної поліції України у системі правоохоронних органів; iï структуру, принципи, методи правоохоронної діяльності, правове забезпечення;

- особливості здійснення профілактичної роботи, спрямованої на запобігання вчиненню кримінальних та інших правопорушень;

- порядок вжиття заходів для забезпечення публічної безпеки і порядку, реагування на заяви та повідомлення про кримінальні та адміністративні правопорушення або події, запобігання та протидії домашньому насильству або насильству за ознакою статі;

- порядок організації роботи щодо взаємодії з населенням;

- порядок здійснення контролю за дотриманням правил безпеки дорожнього pyxy;

- заходи безпеки, умови та порядок зберігання, правила поводження зі спеціальними засобами, табельною вогнепальною зброєю та боєприпасами;

- порядок застосування й використання в межах своєї компетенції поліцейських превентивних заходів та поліцейських заходів примусу (фізичного впливу (сили), спеціальних засобів, вогнепальної зброї);

- правила ділового етикету та професійної етики;

- види та форми звітності; основні нормативно-правові положення щодо зберігання інформації з обмеженим доступом, оформлення відповідних службових документів;

- правила охорони праці та протипожежної безпеки;

- порядок формування та користування базами (банками) даних Національної поліції України, Міністерства внутрішніх справ України [6].

Окрім правових знань поліцейський патрульної поліції повинен володіти додатковою інформацією про: оперативну обстановку і дислокацію інших нарядів поліції, представників громадських об’єднань із забезпечення публічної безпеки і порядку; прикмети осіб, транспортних засобів і майна, яке знаходиться у розшуку; місця найбільш ймовірного скоєння злочинів, скупчення антисоціальних елементів і осіб, звільнених із місць позбавлення волі; місцезнаходження найважливіших об'єктів органів державної влади і управління в регіоні, підрозділів пожежної охорони, гуртожитків, підприємств, організацій та установ тощо; розташування прилеглих до маршруту вулиць, провулків, прохідних дворів, площ тощо [6].

Професійне навчання поліцейських патрульної поліції складається 3 первинної професійної підготовки; подальшої підготовки у закладах вищої освіти зі специфічними умовами навчання; післядипломної освіти; службової підготовки [1].

Поліцейські, які вперше прийняті на службу в поліцію, з метою набуття спеціальних навичок, необхідних для виконання повноважень поліції, зобов'язані пройти первинну професійну підготовку за відповідними навчальними програмами (планами), затвердженими МBC України.

Розподіл випускників закладів вищої освіти зі специфічними умовами навчання, що здійснюють підготовку поліцейських, які навчаються на денній формі навчання за державним замовленням, здійснюється комісіями 3 персонального розподілу з урахуванням інтересів служби відповідно 


\section{Кримінальне право, кримінальний процес та криміналістика}

до набутої випускником кваліфікації, спеціальності та спеціалізації.

Для роботи поліцейським патрульної поліції кандидат повинен мати освітній ступінь «бакалавр»у галузі знань «Право»або у інших галузях знань [20].

Післядипломна освіта (спеціалізація, перепідготовка, підвищення кваліфікації, стажування) може здійснюватися безпосередньо в підрозділах поліції або в закладах вищої освіти. Підвищення кваліфікації за напрямом службової діяльності повинно здійснюватися не рідше одного разу на три роки або перед призначенням на керівну посаду (у тому числі вищу керівну посаду, ніж займана) [21].

3 метою оцінки ділових, професійних, особистих якостей, фізичної підготовки на підставі глибокого і всебічного вивчення, визначення відповідності посадам, а також перспектив їхньої службової кар'єри проводиться атестування працівників поліції [22].

3 урахуванням завдань, напрямів та особливостей організації діяльності поліцейських патрульної поліції визначено наступні найбільш типові помилки, що мають (чи можуть мати) місце в професійній діяльності, та їх можливі наслідки:

1. Недоліки у зборі та оформленні матеріалів про адміністративні правопорушення, невірна кваліфікація правопорушень. Внаслідок помилок судами і адміністративними комісіями виносяться постанови про закриття справ про адміністративні правопорушення.

2. Незазначення всіх необхідних даних у протоколі про адміністративне правопорушення. Можливі наслідки: виправдання правопорушника, або його непритягнення до відповідальності; затягування термінів у судовому розгляді; оскарження рішення щодо притягнення до адміністративної відповідальності; надмірне витрачання людських та матеріальних ресурсів.

3. Недоліки у зборі та оформленні документів у процесі розгляду звернень гро- мадян. Внаслідок помилок - оскарження заявником прийнятих рішень до органів прокуратури, апарату Національної поліції України та ін.

4. Низький рівень знань нормативноправових актів, які стосуються службової діяльності, а також відсутність дисциплінованості та належної етичної поведінки. Можливі наслідки: ненадання громадянам якісної правової допомоги та поліцейських послуг; відсутність самодисциплінованості та прагнення саморозвитку; притягнення до дисциплінарної відповідальності.

5. Перевищення влади чи службових повноважень (безпідставне застосування фізичної сили, незаконне затримання, інше порушення прав і свобод людини), службове підроблення (створення завідомо неправдивих документів, формальні відписки), вчинення корупційних діянь у процесі службової діяльності. Як наслідок - притягнення до адміністративної чи кримінальної відповідальності.

6. Неналежне здійсненні превентивної (профілактичної) роботи з особами, які порушують правила дорожнього руху. Як наслідок - вчинення такими особами адміністративних правопорушень.

7. Ігнорування заходів особистої безпеки під час виконання службових обов'язків, низький рівень знань тактики дій у типових ситуаціях під час несення служби. Як наслідок - високий ризик отримання травматизму та більш тяжких наслідків під час виконання службових обов'язків [5; 6; 23; 24].

\section{Висновки}

Таким чином, узагальнення правових підстав діяльності поліцейських патрульної поліції НПУ дозволяе визначити основні iï правові характеристики, які вирізняють цю професію серед інших. До них зокрема належать наступні:

1. Професія поліцейського патрульної поліції на сьогоднішній день ще нормативно не визначена, а перебуває в межах узагальненої назви професійної роботи. 
2. Поліцейські патрульної поліції виконують широкий спектр завдань професійної діяльності (забезпечення публічного порядку та безпеки, охорони прав і свобод людини, а також інтересів суспільства i держави; запобігання, виявлення та припинення кримінальних та адміністративних правопорушень; забезпечення безпеки дорожнього руху, організація контролю за додержанням законів, інших нормативних актів 3 питань безпеки дорожнього руху, надання послуг з допомоги особам, які 3 особистих, економічних, соціальних причин або внаслідок надзвичайних ситуацій потребують такої допомоги).

3. Аналіз обов'язків та прав поліцейських патрульної поліції свідчить 3 одного боку про наявність у них з одного боку владних повноважень, а з іншого - про високий рівень відповідальності за одноосібність у прийнятті владних рішень.

4. Існує безпосередня залежність результативності й ефективності професійної діяльності патрульних поліцейських від знання ними правових підстав їх діяльності та врахування їх у своїй службовій діяльності.

5. Якісне виконання поліцейським патрульної поліції НПу своїх службових обов'язків вимагає високий рівень їх обізнаності у різних галузях права, а також багатьох спеціальних умінь. Патрульний поліцейський повинен володіти визначеними компетентностями, відповідати загальним умовам вступу на службу в поліцію, постійно підвищувати свою кваліфікацію за напрямом службової діяльності, а також знати про найбільш типові помилки та їх наслідки, що можуть мати місце в професійній діяльності та унеможливлювати настання негативних наслідків.

\section{Лiтература}

1. Про Національну поліцію: Закон України від 02.07.2015 № 580-VIII // Відомості Верховної Ради України. 2015. № 40-41 (від 09.10.2015). Ст. 379. URL: http:// zakon2.rada.gov.ua/laws/show/580-19 (дата звернення: 03.02.2020).

2. Національний класифікатор України «Класифікатор професій» ДК 003:2010, затверджений наказом Держспоживстандарту України від 28.07.2010 № 327 (чинний від 01.11.2010): сайт. URL: https:/hrliga. com/docs/327_KP.htm (дата звернення: 03.02.2020).

3. Про Державну службу: Закон України від 10.12.2015 № 889-VIII // Відомості Верховної Ради України. 2016. № 4 (від 22.01.2016). Ст. 43. URL: http://zakon2.rada. gov.ua/laws/show/889-19 (дата звернення: 03.09.2019).

4. Про затвердження Положення про Національну поліцію: постанова Кабінету Міністрів України від 28.10.2015 № 877 // Офіційний вісник України. 2015. № 89 (від 17.11.2015). Стор. 34. Ст. 2971. Код акту 79257/2015. URL: http://zakon2.rada.gov. ua/laws/show/877-2015-п (дата звернення: 03.02.2020).

5. Про затвердження Положення про Департамент патрульної поліції: наказ МВС України від 06.11.2015 № 73 (у редакції наказу Національної поліції від 31.10.2016 року № 1114 «Про внесення змін до Положення про Департамент патрульної поліції») // URL: http://zakon2.rada. gov.ua/laws/show/z0559-17 (дата звернення: 03.02.2020).

6. Про затвердження Положення про патрульну службу MBC: наказ МВС України від 06.11.2015 № 796 // Офіційний вісник України. 2015 р., № 54, стор. 203, стаття 1767, код акта 77561/2015 URL: https:/ zakon.rada.gov.ua/laws/show/z0777-15 (дата звернення: 03.02.2020).

7. Конституція України: Закон України від 28.06.1996 № 254к/96-ВР. Поточна редакція від 30.09.2016 // Відомості Верховної Ради України. 1996. № 30 (від 23.07.1996). Ст. 141. URL: http://zakon5.rada.gov.ua/ laws/show/254к/96-вр (дата звернення: 03.02.2020). 


\section{Кримінальне право, кримінальний процес та криміналістика}

8. Про Дисциплінарний статут Національної поліції України: Закон України від 15.03.2018 № 2337-VIII // Відомості Верховної Ради. 2018. № 29, ст. 233.

9. Про запобігання корупції: Закон України від 14.10.2014 № 1700-VII // Відомості Верховної Ради. 2014. № 49, ст.2056.

10. Про захист персональних даних: Закон України від 01.06.2010 № 2297-VI // Відомості Верховної Ради України. 2010. № 34 , ст. 481.

11. Про доступ до публічної інформації: Закон України від 13.01.2011 № 2939-VI // Відомості Верховної Ради України. 2011. № 32, ст. 314.

12. Про звернення громадян: Закон України від 02.10.1996 № 393/96-ВР // Відомості Верховної Ради України. 1996. № 47, ст. 256 .

13. Про дорожній рух: Закон України від 30.06.1993 року № 3353-XII // Відомості Верховної Ради України (ВВР), 1993, № 31, ст. 338.

14. Кодекс України про адміністративні правопорушення від 07.12.1984, № 807410 // Відомості Верховної Ради Української РСР (ВВР) 1984, додаток до № 51, ст. 1122.

15. Кримінальний кодекс України від 05.04.2001 № 2341-III // Відомості Верховної Ради України. 2001. № 25-26, ст. 131.

16. Кримінальний процесуальний кодекс України від 13.04.2012 № 4651-VI // Biдомості Верховної Ради України., 2013. № 9-10, № 11-12, № 13, ст. 88.

17. Про Правила дорожнього руху: Постанова Кабінету Міністрів України від 10.10.2001 № 1306 // URL: https://zakon. rada.gov.ua/laws/show/1306-2001-\%D0\%BF (дата звернення: 03.02.2020).

18. Положенням про Департамент патрульної поліції: наказ НПУ від 06.11.2015 № 73. URL: http://patrol.police.gov.ua/wpcontent/uploads/2016/03/Polozhennya_DPP_ zi_zminamy_vid_31_10_16.pdf (дата звернення: 03.02.2020).

19. Аіпницький В.А. Деякі правові проблеми підготовки поліцейських в умо- вах реформування системи МВС України // Особливості підготовки поліцейських в умовах реформування системи МВС України: 3б. матеріалів I міжнар. наук.-практ. конф. (Харків, 20 трав. 2016 р.) / Харків. нац. ун-т внутр. справ. Харків: ХНУВС, 2016. C. $78-81$.

20. Про затвердження Порядку розроблення та затвердження кваліфікаційних характеристик: наказ Міністерства соціальної політики України від 31.05.2017 № 918 // Офіційний вісник України. 2017. № 67. Стор. 119. Ст. 2016. Код акту 86882/2017. URL: http://zakon2.rada.gov.ua/laws/show/ z0784-17 (дата звернення: 03.02.2020).

21. Про затвердження Положення про організацію післядипломної освіти працівників Національної поліції: наказ МВС України від 24.12.2015 № 1625 // Офіційний вісник України. 2016. № 11 (від 16.02.2016). Стор. 173. Ст. 485. Код акту 80657/2016. URL: http://zakon0.rada.gov.ua/laws/show/ z0076-16 (дата звернення: 03.02.2020).

22. Про затвердження Інструкції про порядок проведення атестування поліцейських: наказ МВС України від 17.11.2015 № 1465 // Офіційний вісник України. 2015. № 90 (від 20.11.2015). Стор. 234. Ст. 3073. Код акту 79475/2015. URL: http://zakon2. rada.gov.ua/laws/show/z1445-15 (дата звернення: 03.02.2020).

23. Професіографічна характеристика основних видів діяльності в органах внутрішніх справ України (кваліфікаційні характеристики професій, професіограми основних спеціальностей): довід. посіб. / М. І. Ануфрієв, Ю. Б. Ірхін, М. Н. Курко, Т. В. Нещерет, С. В. Омельченко, В. В. Синявський, О. В. Шаповалов. Київ: МВС України; КІВС, 2003. 80 с.

24. Професіографічний опис основних видів діяльності в органах внутрішніх справ України: практ. посіб. / В. І. Барко, Ю. Б. Ірхін, Т. В. Нещерет, О. В. Шаповалов. Київ: КНУВС, Друкарня МВС, 2007. $100 \mathrm{c}$. 


\section{АНОТАЦІЯ}

Стаття присвячена дослідженню правових підстав діяльності поліцейсъких патрульної полічиї Національної полічиї Украӥни. Перед сучасною патрульною полічією Начіональної полічій України съогодні поставлені важливі завдання. Насамперед, ие забезпечення публічного порядку та безпеки, охорони прав і свобод людини, інтересів суспільства і держави; запобігання, виявлення та припинення кримінальних та адміністративних правопорушень; забезпечення безпеки дорожнъого руху, організація контролю за додержанням законів, інших нормативних актів 3 питань безпеки дорожнъого руху, надання послуг з допомоги особам, які з особистих, економічних, сочіальних причин або внаслідок надзвичайних ситуаиій потребують такої допомоги. Від підрозділів патрульної поліий очікується суттєве покрашання й підвищення ефективності діяльності, яке грунтується на доборі персоналу з високим рівнем пробесійної придатності до виконання обов'язків, подальшому підвищенні професійної підготовленості поліщейсъких, досягнення більи вагомих результатів у справі боротьби зі злочинністю $i$ захисті конституиійних прав $i$ свобод громадян.

Важливою складовою якісного кадрового забезпечення підрозділів патрульної полічиї Національної полічиї Украӥни квалібікованим персоналом $є$ добір на основі об'єктивного оцінювання наявності необхідних компетениій - правових знань, а також багатьох спеиіальних умінъ. Тому особливої актуальності набуває съогодні вивчення правових підстав діяльності поліщейсъкого патрульної полічій Національной поліиї України. Правова підготовка та правова обізнаність поліщейсъких патрульної полічій $\epsilon$ необхідною передумовою вирішення проблем, пов'язаних з ебективним виконанням своӥх професійних обов'язків, підвищення їх кваліфікаиї, підготовки та перепідготовки, раціоналізацією режимів $і$ умов праці, зниженням травматизму і пробесійних захворювань.

y статті розглянуто нормативне визначення професій поліщейсъкого патрульної полічій НПУ; проаналізовані завдання, обов'язки, відповідальність та права патрульних; визначені основні принципи, якими має керуватися патрульний у свой профбесійній діяльності; встановлені вимоги, яким має відповідати кандидат для роботи поліщейсъким патрульної поліщї; виявлені найбільш типові помилки, що можуть мати місце в діяльності патрульного та їх можливі наслідки.

Ключові слова: Начіональна полічія Украӥни, патрульна полічія, правові підстави пробесійної діяльності.

\section{SUMMARY}

The article is devoted to the investigation of legal grounds of patrol police officers' professional activity. Contemporary officers of patrol police of the National Police of Ukraine perform different tasks. First of all officers must ensure public order and security, the protection of human rights and freedoms, the interests of society and the state; prevention, detection and termination of criminal and administrative offenses; ensuring road safety, organizing compliance with laws, other regulations on road safety, providing assistance services to persons who, for personal, economic, social or emergency situations, require such assistance. Patrol police units are expected to substantially improve performance based on the selection of staff with a high level of professional competence to perform their duties, further enhance the professional skills of police officers, achieve greater results in the fight against crime and the protection of constitutional rights .

An important component of the effective activity of patrolling units of the National Police of Ukraine is professional staff selection, based on an objective assessment of the availability of the necessary competencies - legal knowledge, as well as many special skills. That is why the study of legal grounds of activity of the patrol police officers of the National police of Ukraine becomes especially relevant today. Legal training and legal awareness of patrolling police is a prerequisite for solving problems related to the effective performance of their professional duties, improving their skills, training and retraining, rationalization of working conditions, reduction of injuries and occupational diseases.

The article deals with the normative definition of the profession of the patrol police officer of the National police of Ukraine; analyzed tasks, duties, responsibilities and rights of patrol officers; outlined the basic principles that the patrol officer should follow in his professional activity; the requirements to be met by the candidate for the position of police patrol officers; identified the most common mistakes that may occur in patrol activities and their possible consequences.

Keywords: National police of Ukraine, patrol police, legal grounds for professional activity. 